\title{
PERANCANGAN ALAT TIMBANGAN DIGITAL BERBASIS ARDUINO LEONARDO MENGGUNAKAN SENSOR LOAD CELL
}

\author{
Abdul Muis Muslimin ${ }^{1 *}$, Titin Lestari $^{2}$ \\ 1,2 Prodi Fisika FMIPA UNIPA \\ email korespondensi: a.muslimin@unipa.ac.id
}

\begin{abstract}
ABSTRAK
Kemajuan teknologi membawa perubahan pada peralatan-peralatan yang dahulu bekerja secara analog, mulai dikembangkan dengan teknik digital dan bahkan yang bekerja secara manual sekarang mulai banyak dikembangkan secara otomatis, seperti halnya alat timbang digital. Timbangan digital merupakan alat ukur untuk mengukur massa benda atau zat dengan tampilan digital. Penelitian ini dibuat dengan tujuan menghasilkan sebuah alat timbangan digital berbasis board Arduino Leonardo. Arduino Leonardo telah terintegrasi dengan mikrokontroler Atmega32u4, menggunakan load cell sebagai sensor beban dengan tampilan nilai beban menggunakan LCD jenis $16 \times 2$ sehingga hasil pengukuran dapat lebih mudah dibaca dan memiliki ketelitian yang lebih baik dibanding timbangan analog. Pengujian alat dilakukan dengan membandingkan antara timbangan yang dibuat dengan timbangan standar. Peralatan yang dibuat mendekati tingkat akurasi peralatan standar (Kern PCB 1000-2), dimana selisih rata-rata adalah 0,66 gram.
\end{abstract}

Kata Kunci : Timbangan Digital, Sensor Load Cell, ArduinoLeonardo, LCD

\section{PENDAHULUAN}

Timbangan adalah sebuah alat
bantu yang digunakan secara tidak langsung untuk mengetahui massa suatu benda. Jenis timbangan yang digunakan bermacam - macam, mulai dari timbangan manual/analog dan timbangan digital. Timbangan digital merupakan alat ukur untuk mengukur massa benda atau zat dengan tampilan digital. Dalam pemanfaatannya timbangan digunakan diberbagai bidang, dari perdagangan industri sampai dengan perusahaan jasa. Timbangan digital mempunyai tingkat ketelitian yang lebih baik dan pengoperasian yang lebih efesien daripada timbangan analog. Pada timbangan digital, pengguna dapat melihat angka yang tertera pada layar LCD (Liquid Crystal Display). 
Pemanfaatan dari kedua jenis timbangan ini hanya digunakan untuk mengukur besaran massa. Timbangan digital mempunyai tingkat akurasi yang lebih tinggi dibanding timbangan analog. Timbangan digital dapat mengukur berat elemen-elemen yang kecil seperti satu butir pasir dengan akurasi yang lebih baik, sedangkan timbangan analog tidak cukup sensitif untuk mencatat beban rendah seperti elemen-elemen yang kecil. Hal ini membuat timbangan digital banyak dipakai di laboratorium dimana partikel yang paling kecil dapat diukur. Akurasi tidak saja terbatas pada penimbangan yang kecil, timbangan digital juga lebih akurat untuk menunjukan berat keseluruhan.

Berdasarkan permasalah tersebut, maka dirancang sebuah alat yang mampu mengukur massa dan dilengkapi dengan tampilan hasil berupa angka untuk mempermudah pemakai dalam melihat hasil pengukuran alat.

Dalam penelitian ini dirancang dan dibuat sebuah alat timbangan elektronik menggunakan mikrokontroler sebagai pengendali. Pada timbangan digital ini digunakan sensor beban load cell sebagai pendeteksi massa. Setelah ditimbang maka dihasilkan nilai atau sensor value dan timbangan ini akan tersimpan pada EEPROM (Electrically Erasablle Programmable Read-Only Memory) mikrokontroler. Pada saat beban diletakkan diatas timbangan nilai massanya otomatis akan diproses oleh mikrokontroler Atmega32u4 dan hasilnya akan ditampilkan pada layar LCD (Liquid Crystal Display).

Tujuan dilakukannya penelitian ini adalah Merancang dan menghasilkan sebuah alat timbangan digital berbasis Arduino Leonardo dengan tampilan menggunakan LCD jenis 16x2 sehingga hasil pengukuran dapat lebih baik dan mudah dibaca.

\section{METODE PENELITIAN}

Tahapan yang dilakukan dalam metode penelitian ini diawali dengan studi literatur, dilanjutkan dengan perancangan hardware, perancangan software dan pengujian alat.

\section{II.1. Perancangan Hardware}

Alat yang digunakan dalam pembuatan dan penelitian ini adalah :

1. Laptop

2. Timbangan digital standar (untuk pengujian alat) merek Kern PCB 1000-2 3. Solder Listrik 
Bahan yang digunakan pada penelitian dan pembuatan ini adalah :

1. Timah, Module HX711

2. Papan PCB, Baterai

3. Sensor load cell, Wadah / Botol

4. Mikrokontroler, Spacer

5. LCD character, Kabel Pelangi.

6. Box untuk meletakkan alat/rangkaian

\section{II.2. Blok Diagram Hardware}

Blok rangkaian yang digunakan dalam penelitian ini dapat dilihat pada Gambar 1.

Diagram blok pada Gambar 1, digunakan sebagai dasar dalam perancangan Alat Timbangan Digital Berbasis Arduino Leonardo menggunakan Sensor Load Cell. Adapun fungsi setiap Blok diatas adalah :
1. Baterai: Sumber tegangan listrik

2. Sensor Load Cell: Komponen alat yang berfungsi untuk mendeteksi beban

3. Modul HX711 : Komponen alat yang berfungsi untuk menguatkan sinyal dan mengkonversikan sinyal dialog ke sinyal digital.

4. Arduino Leonardo: Memproses data dari sensor load cell

5. LCD: Penampil data nilai massa beban Pada sistem ini jika pada sensor load cell diberikan beban maka beban akan memberikan tekanan terhadap sensor, dan nilai tekanan tersebut dikonversi oleh sensor menjadi tegangan listrik. Namun karena sinyal yang dihasilkan oleh sensor masih sinyal

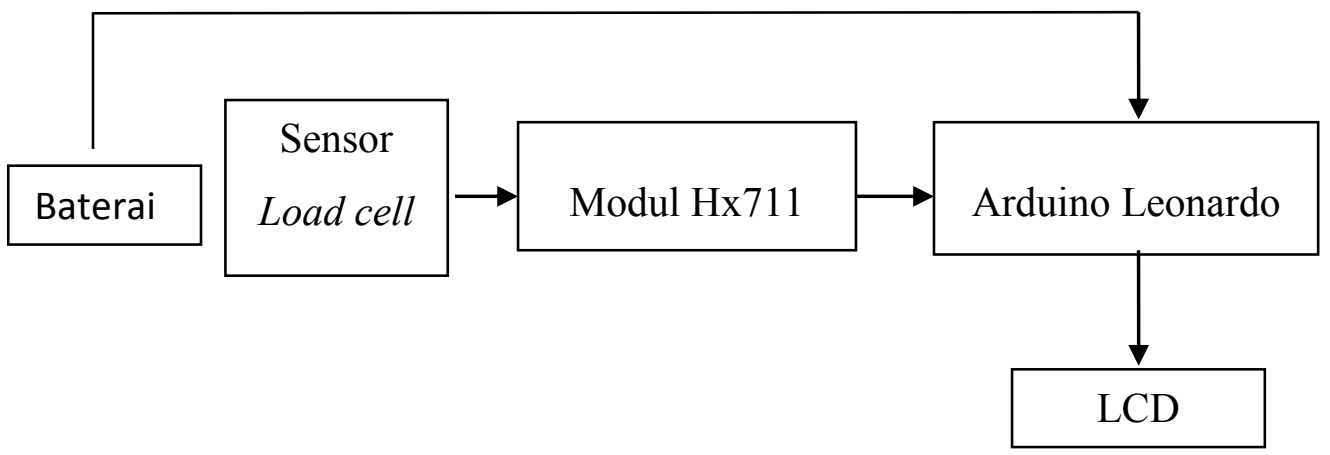

Gambar 1. Blok diagram rangkaian timbangan digital 
analog maka dikonversikan menjadi sinyal digital dengan menggunakan Hx711.Selanjutnya sinyal-sinyal yang dihasilkan oleh Hx711 dijadikan input arduino leonardo. Setelah data dikonversikan oleh arduino leonardo maka sinyal-sinyal tersebut diproses dan ditampilkan nilai beban ke LCD.

\section{II.3. Skema Rangkaian Timbangan Digital}

Skema rangkaian hardware timbangan digital yang terdiri board Arduino, sensor load cell, modul HX711 dan LCD dapat dilihat pada Lampiran 1.

\section{II.4. Perancangan Software}

Agar timbangan digital dapat berfungsi, setelah dilakukan merangkai hardware, maka dibutuhkan kode program (sketch) yang akan diupload ke mikrokontroler ATMega32u4 yang terdapat pada board Arduino Leonardo. Dalam merancang suatu perangkat lunak yang rumit didahului dengan flowchart system. Flowchart dapat digunakan untuk menggambarkan suatu algoritma (menggunakan gambar - gambar yang sesuai). Kegunaan flowchart ini sangat penting terutama pada pengecekan program.

Tahapan-tahapan yang akan di proses dalam perancangan software adalah sebagai berikut :

1. Program akan dimunculkan setelah mikrokontroler mendapatkan tegangan listrik.

2. Inisialisasi PORT pada sensor beban untuk mengaktifkan port yang akan digunakan dalam proses komunikasi data.

3. Timbangan mendapatkan beban setelah port terinisialisasi, apabila kita meletakkan sebuah beban kepermukaan sensor maka beban tersebut akan memberikan tekanan terhadap permukaan sensor

4. Pembacaan nilai sensor, nilai yang dibaca ini merupakan nilai tekanan yang dhasilkan dari konversi tekanan beban menjadi tegangan listrik

5. Pemrosesan massa beban merupakan nilai tegangan yang dibaca oleh sensor dan kemudian dilakukan penskalaan/penguatan nilai pembacaan sensor

6. Kalibrasi data berfungsi untuk meningkatkan akurasi dari massa beban yang diukur

7. Hasil nilai beban ditampilankan di LCD

8. Selesai 
Diagram perancangan software (sketch) timbangan digital dapat dilihat pada Gambar 2.

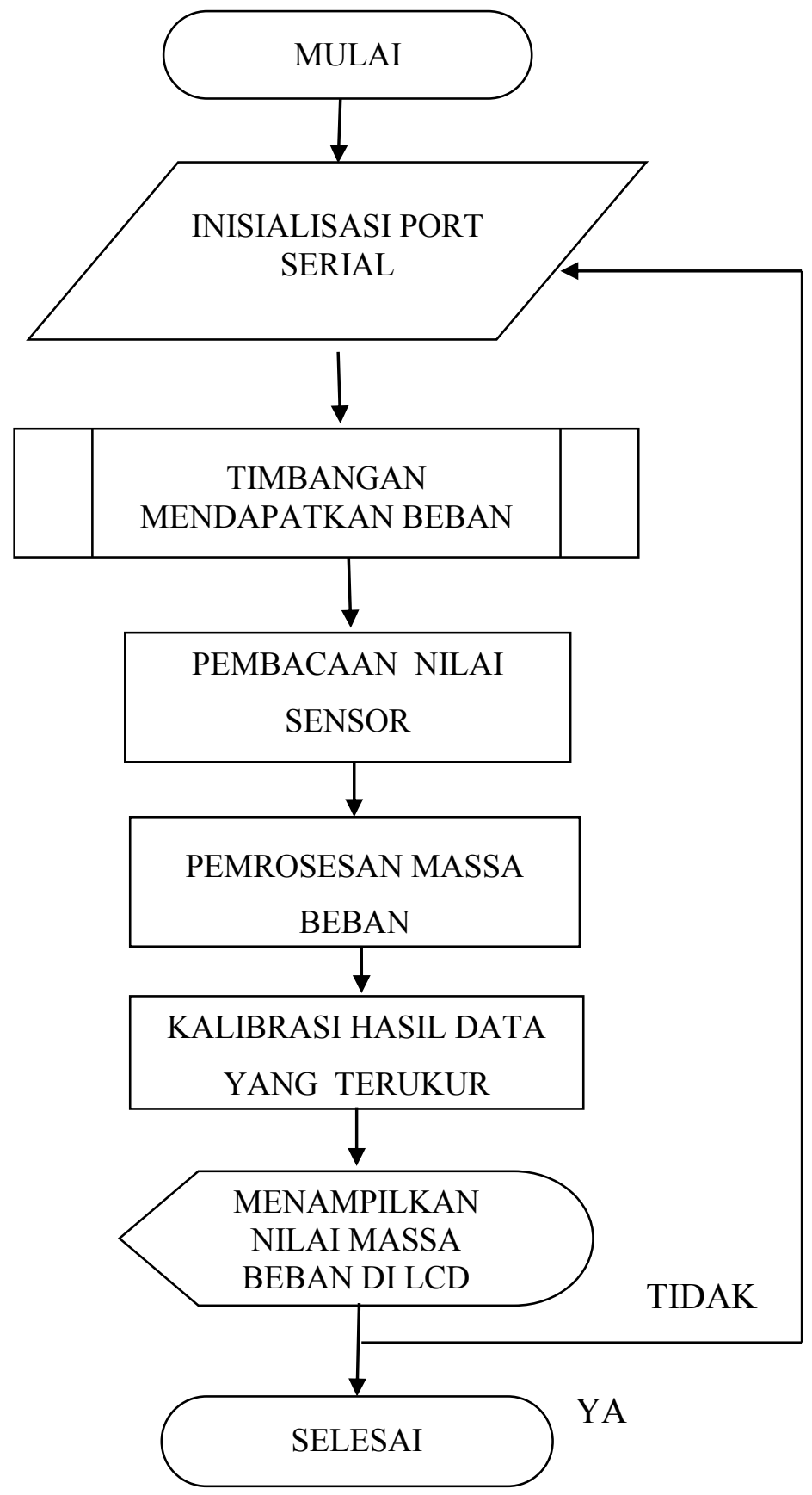

Gambar 2. Diagram perancangan software (sketch) timbangan 


\section{HASIL DAN PEMBAHASAN}

Dalam bab ini akan diuraikan bagaimana hasil dari pengujian rancangan alat yang dibuat beserta pembahasan tentang nilai sensor berat dan kalibrasi dari perancangan timbangan digital berbasis arduino leonardo menggunakan sensor load cell. Pengujian tersebut menggunakan perangkat elektronik yang dirancang dan diprogram dengan applikasi Arduino.

\section{III.1. Tampilan Hasil Perangkat Timbangan Digital}

Berikut adalah tampilan hasil perancangan dan implementasi timbangan digital berbasis mikrokontroler, ditunjukkan oleh Gambar 3.

\section{III.2. Pengujian Rangkaian Sensor Load}

Cell

Load cell sebagai sensor berat yang mengirimkan data berat terhadap objek yang diukur. Pengujian ini dilakukan dengan mencoba memberikan objek pada load sensor dan hasil data ditampilkan dilayar LCD 16x2 dari mikrokontroler. Data pembanding yang digunakan adalah timbangan standar dengan pengambilan data 0,1 gram- 2200 gram. Berikut adalah hasil dari pengukuran sensor load cell terhadap timbangan standar.

Pengujian Timbangan Digital Berbasis Mikrokontroler Menggunakan Metode Regresi Polynomial Orde 2

Adapun pengujian dari timbangan digital berbasis mikrokontroler menggunakan metode regresi polynomial orde 2 dapat diperoleh hasil pada Tabel 1.

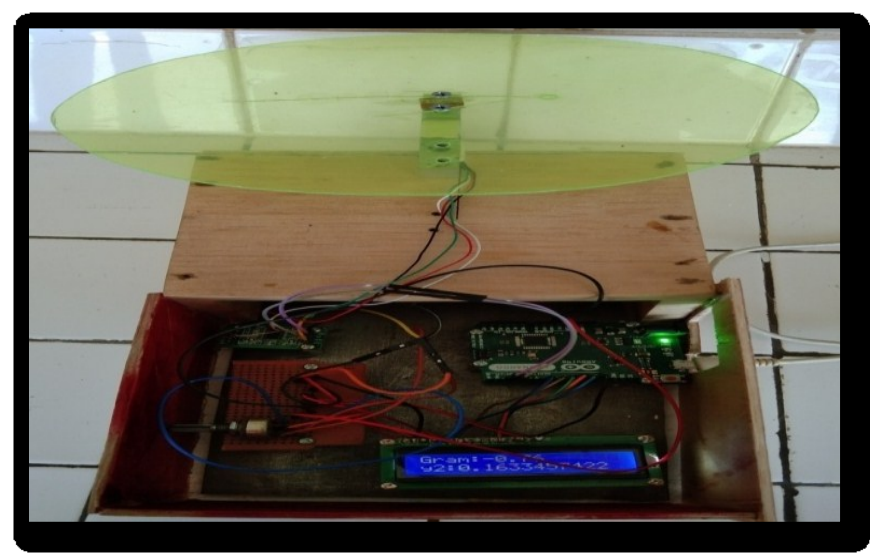

Gambar 3. Perangkat Timbangan Digital 
Tabel 1. Data Polynomial Orde 2 Hasil Pengujian Sensor Load Cell

\begin{tabular}{|c|c|c|c|}
\hline \multirow[b]{2}{*}{$\begin{array}{c}\text { NO } \\
\text { PENGUJIAN }\end{array}$} & \multicolumn{2}{|c|}{ HASIL PENGUKURAN } & \multirow[b]{2}{*}{$\begin{array}{c}\text { ERROR } \\
\text { (gr) }\end{array}$} \\
\hline & $\begin{array}{c}\text { Timbangan } \\
\text { Standar } \\
\text { (gr) }\end{array}$ & $\begin{array}{c}\text { Timbangan } \\
\text { Mikrokontroler } \\
\text { (gr) }\end{array}$ & \\
\hline 1 & 0 & 0,11 & 0,11 \\
\hline 2 & 40,4 & 40,21 & 0,19 \\
\hline 3 & 51,72 & 51,25 & 0,47 \\
\hline 4 & 62,61 & 62,33 & 0,28 \\
\hline 5 & 72,24 & 72,03 & 0,21 \\
\hline 6 & 81,32 & 81,35 & 0,03 \\
\hline 7 & 91,45 & 91,47 & 0,02 \\
\hline 8 & 101,83 & 102,04 & 0,21 \\
\hline 9 & 111,44 & 111,54 & 0,1 \\
\hline 10 & 121,49 & 121,11 & 0,38 \\
\hline 11 & 132,3 & 131,85 & 0,45 \\
\hline 12 & 181,17 & 181,2 & 0,03 \\
\hline 13 & 231,69 & 231,36 & 0,33 \\
\hline 14 & 281,39 & 281,01 & 0,38 \\
\hline 15 & 331,8 & 331,34 & 0,46 \\
\hline 16 & 382,87 & 382,34 & 0,53 \\
\hline 17 & 432,08 & 431,37 & 0,71 \\
\hline 18 & 482,39 & 482,06 & 0,33 \\
\hline 19 & 499,54 & 498,96 & 0,58 \\
\hline 20 & 582,18 & 581,71 & 0,47 \\
\hline 21 & 632,43 & 632,08 & 0,35 \\
\hline 22 & 682,44 & 681,76 & 0,68 \\
\hline 23 & 732,83 & 732,2 & 0,63 \\
\hline 24 & 748,8 & 751,36 & 2,56 \\
\hline 25 & 765,28 & 767,21 & 1,93 \\
\hline 26 & 781,77 & 782,55 & 0,78 \\
\hline 27 & 812,1 & 812,84 & 0,74 \\
\hline 28 & 831,74 & 833,05 & 1,31 \\
\hline 29 & 851,61 & 852,43 & 0,82 \\
\hline 30 & 883,22 & 883,7 & 0,48 \\
\hline 31 & 901,64 & 901,87 & 0,23 \\
\hline 32 & 932,24 & 932,12 & 0,12 \\
\hline 33 & 953,54 & 952,51 & 1,03 \\
\hline 34 & 981,88 & 981,22 & 0,66 \\
\hline 35 & 998,99 & 997,53 & 1,46 \\
\hline 36 & 1082 & 1078,29 & 3,71 \\
\hline 37 & 1133 & 1133,61 & 0,61 \\
\hline 38 & 1183 & 1184,09 & 1,09 \\
\hline 39 & 1236 & 1236,8 & 0,8 \\
\hline
\end{tabular}




\begin{tabular}{|c|c|c|c|}
\hline \multirow[b]{2}{*}{$\begin{array}{c}\text { NO } \\
\text { PENGUJIAN }\end{array}$} & \multicolumn{2}{|c|}{ HASIL PENGUKURAN } & \multirow[b]{2}{*}{$\begin{array}{l}\text { ERROR } \\
\quad(\mathrm{gr})\end{array}$} \\
\hline & $\begin{array}{c}\text { Timbangan } \\
\text { Standar } \\
\text { (gr) }\end{array}$ & $\begin{array}{c}\text { Timbangan } \\
\text { Mikrokontroler } \\
\text { (gr) }\end{array}$ & \\
\hline 40 & 1283 & 1283,92 & 0,92 \\
\hline 41 & 1330 & 1331,34 & 1,34 \\
\hline \multirow[b]{2}{*}{$\begin{array}{c}\text { NO } \\
\text { PENGUJIAN }\end{array}$} & \multicolumn{2}{|c|}{ HASIL PENGUKURAN } & \multirow[b]{2}{*}{$\begin{array}{c}\text { ERROR } \\
\quad(\mathrm{gr})\end{array}$} \\
\hline & $\begin{array}{c}\text { Timbangan } \\
\text { Standar } \\
\text { (gr) }\end{array}$ & $\begin{array}{c}\text { Timbangan } \\
\text { Mikrokontroler } \\
\text { (gr) }\end{array}$ & \\
\hline 41 & 1330 & 1331,34 & 1,34 \\
\hline 42 & 1379 & 1379,85 & 0,85 \\
\hline 43 & 1438 & 1438,78 & 0,78 \\
\hline 44 & 1483 & 1484,77 & 1,77 \\
\hline 45 & 1532 & 1508,83 & 23,17 \\
\hline 46 & 1616 & 1616,12 & 0,12 \\
\hline 47 & 1666 & 1666,8 & 0,8 \\
\hline 48 & 1716 & 1715,85 & 0,15 \\
\hline 49 & 1768 & 1767,97 & 0,03 \\
\hline 50 & 1818 & 1818,91 & 0,91 \\
\hline 51 & 1872 & 1872,96 & 0,96 \\
\hline 52 & 1917 & 1917,65 & 0,65 \\
\hline 53 & 1964 & 1964,32 & 0,32 \\
\hline 54 & 2013 & 2014,08 & 1,08 \\
\hline 55 & 2070 & 2071,16 & 1,16 \\
\hline 56 & 2154 & 2155,12 & 1,12 \\
\hline 57 & 2204 & 2205,86 & 1,86 \\
\hline 58 & 2254 & 2254,95 & 0,95 \\
\hline 59 & 2306 & 2307,77 & 1,77 \\
\hline & Rata Error 0 - & & 0,66 \\
\hline & a Error 1000 & & 1,88 \\
\hline
\end{tabular}

(Sumber : Data Primer, 2021)

Dari hasil perhitungan error pada

Tabel 1, pengujian timbangan digital berbasis mikrokontroler menggunakan metode regresi polynomial orde 2 menunjukkan bahwa sebagian besar memiliki nilai error positif yakni ada 33 data, hal ini berarti nilai pengukuran timbangan mikrokontroler lebih tinggi dari nilai pengukuran timbangan standar. Namun terdapat 26 data yang menunjukkan nilai pengukuran timbangan standard lebih tinggi dari nilai pengukuran timbangan mikrokontroler, hal ini berati nilai error positif lebih tinggi dibandingkan dengan nilai error negatif. Jika ditampilkan dalam bentuk grafik, sebaran titik-titik datanya dapat dilihat pada Gambar 4. 


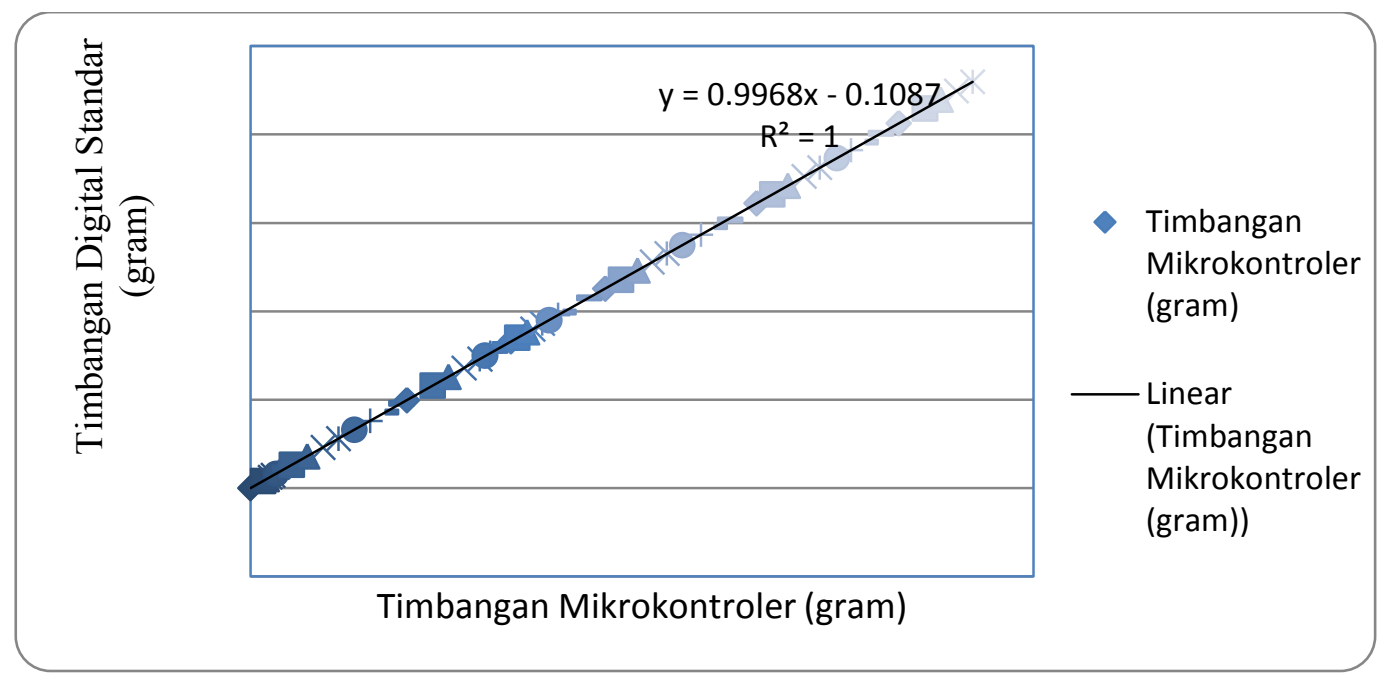

Gambar 4. Grafik Perbandingan Pengujian Polynomial Orde 2 Timbangan Mikrokontroler Terhadap Timbangan Standar Kern PCB 1000-2.

Berdasarkan Tabel 1 dan Gambar 4 dapat disimpulkan bahwa error dari perhitungan massa timbangan mikrokontroler dan timbangan standar dengan massa beban 0 s/d 1000 gr memiliki rata - rata error sebesar $(0,66 \mathrm{gr})$ dimana nilai rata- rata error di absolutkan dalam setiap pengukuran karena tidak dapat dijadikan nilai rata-rata yang mutlak. Grafik diatas menunjukan bahwa pengujian timbangan mikrokontroler menggunakan sensor load cell dan alat timbangan digital standar membentuk polynomial orde 2 .

Dari hasil pengujian timbangan digital berbasis mikrokontroler menggunakan metode regresi polynomial orde 2 dengan massa beban $0 \mathrm{~s} / \mathrm{d} 1000 \mathrm{gr}$, diperoleh data linier memiliki rata-rata error lebih kecil (0,66 gr), namun untuk beban yang lebih besar dari 1000 gr memiliki nilai rata-rata eror ( $1,88 \mathrm{gr})$, tidak menghasilkan data yang linier.

\section{KESIMPULAN}

Berdasarkan penelitian yang telah dilakukan selama proses perancangan, pembuatan dan pengujian alat dapat disimpulkan:

a. Secara keseluruhan alat yang dibuat dapat bekerja dan berfungsi sebagaimana yang diharapkan, sehingga dapat dimanfaatkan sebagai alat timbang digital yang mampu 
menampilkan nilai massa beban secara otomatis pada LCD dengan mikrokontroler Atmega32u4 sebagai pengendali utama.

b. Kemampuan pada timbangan mikrokontroler berdasarkan beban sensor load cell hingga sampai berat beban maksimal yang dimiliki oleh sensor yaitu sekitar 2200 gram.

c. Alat timbangan digital yg dibuat dengan metode regresi polynomial orde 2 memiliki rata-rata selisih/error sebesar $(0,66$ gr) terhadap timbangan digital standar.

\section{DAFTAR PUSTAKA}

Ainul F.A, 2016. Rancang Bangun Timbangan Beras Dengan Keluaran Berat Dan Harga Berbasis Mikrokontroller. UIN Alaudin Makasar.

Blum J, 2020, Exploring Arduino: Tools and Techniques for Engineering Wizardry, John Wiley \& Sons, Inc., Indianapolis

Cameron N, 2019, Arduino Applied: Comprehensive Projects for Everyday Electronics, Apress, New York

Fitriani, 2009.Timbangan Digital Berbasis Mikrokontroler AVRATMega 8535.Skripsi, Fakultas Teknik
Industri.Universitas

Mercu Buana.Jakarta.

Khakim A.L, 2015.Rancang Bangun Alat Timbangan Digital Berbasis AVR TIPE ATMega32.Fakultas Teknik.Universitas Negeri Semarang

Majid Gilang, 2017.Timbangan Digital Berbasis Mikrokontroler AVRATMega 8535. Skripsi, Fakultas Matematiika Dan Ilmu Pengetahuan Alam.Universitas Sumatra Utara. Medan.

Margolis M, Arduino Cookbook, O'Reilly Media, Inc., California

Muhammadihza F. 2018. Timbangan Digital Berbasis Mikrokontroler ATMega 328P.Fakultas Matematika dan Ilmu Pengetahuan Alam (FMIPA).Universitas Sumatra Utara. Medan

Setianingrum P.C, 2017. Timbangan Buah Digital Berbasiskan Mikrokontroler Dengan Output Suara.Universitas Sanata Dharma. Yogyakarta

Setiawan, A., 2011, 20 Aplikasi Mikrokontroler ATmega8535 dan ATmega16, Andi Offset, Yogyakarta.Tip

Priskila M.N Manege,Elia Kendek Allo, Bahrun,2017. Rancang Bangun Timbangan Digital Dengan Kapasitas $20 \mathrm{Kg}$ Berbasis Mikrokontroler ATMega8535.Jurnal Elektro dan Komputer UNSRAT.Vol. VI No. 1.Januari 2017. 
Simarmata, Janner. 2006. Pengenalan Teknologi Komputer dan Informasi. Yogyakarta : Andi Offset

Suci Meilfa Antas, 2017.Perancangan Timbangan Digital Buah Dengan luaran Massa Dan Harga Menggunakan Sensor Load Cell Berbasis ATMega 328P. Fakultas
Matematika Dan Ilmu Pengetahuan Alam.Universitas Sumatra Utara. Medan

Try Utami Hidayani dan Tri Miharani, 2013.Rancang Bangun Timbangan Buah Digital Dengan Keluaran Berat Dan Harga. Skripsi,Fakultas Teknik Komputer, AMIK GI MDP 
Lampiran 1. Skema rangkaian timbangan digital

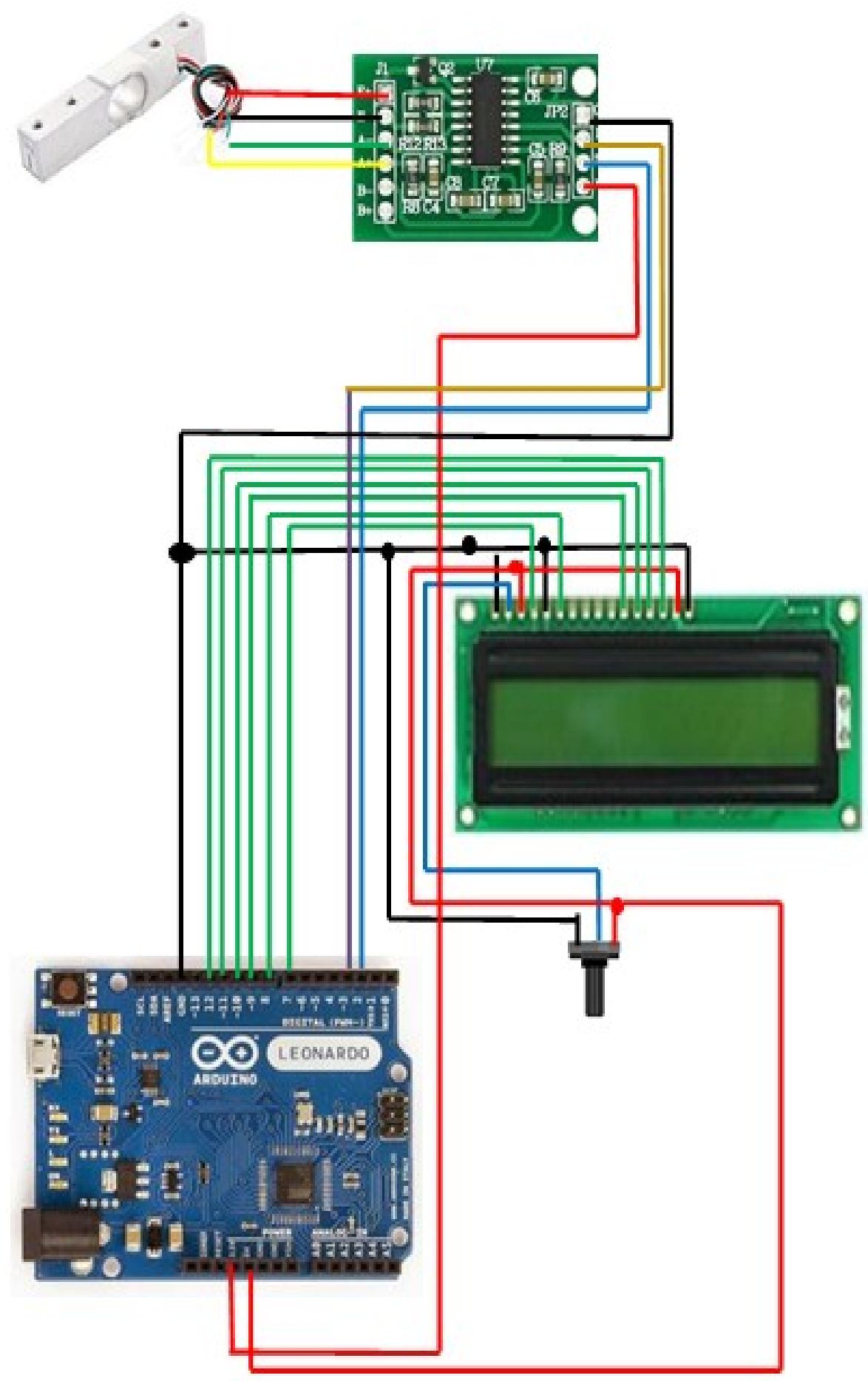

Gambar a. Skema rangkaian timbangan digital 
Lampiran 2. Kode program arduino leonardo

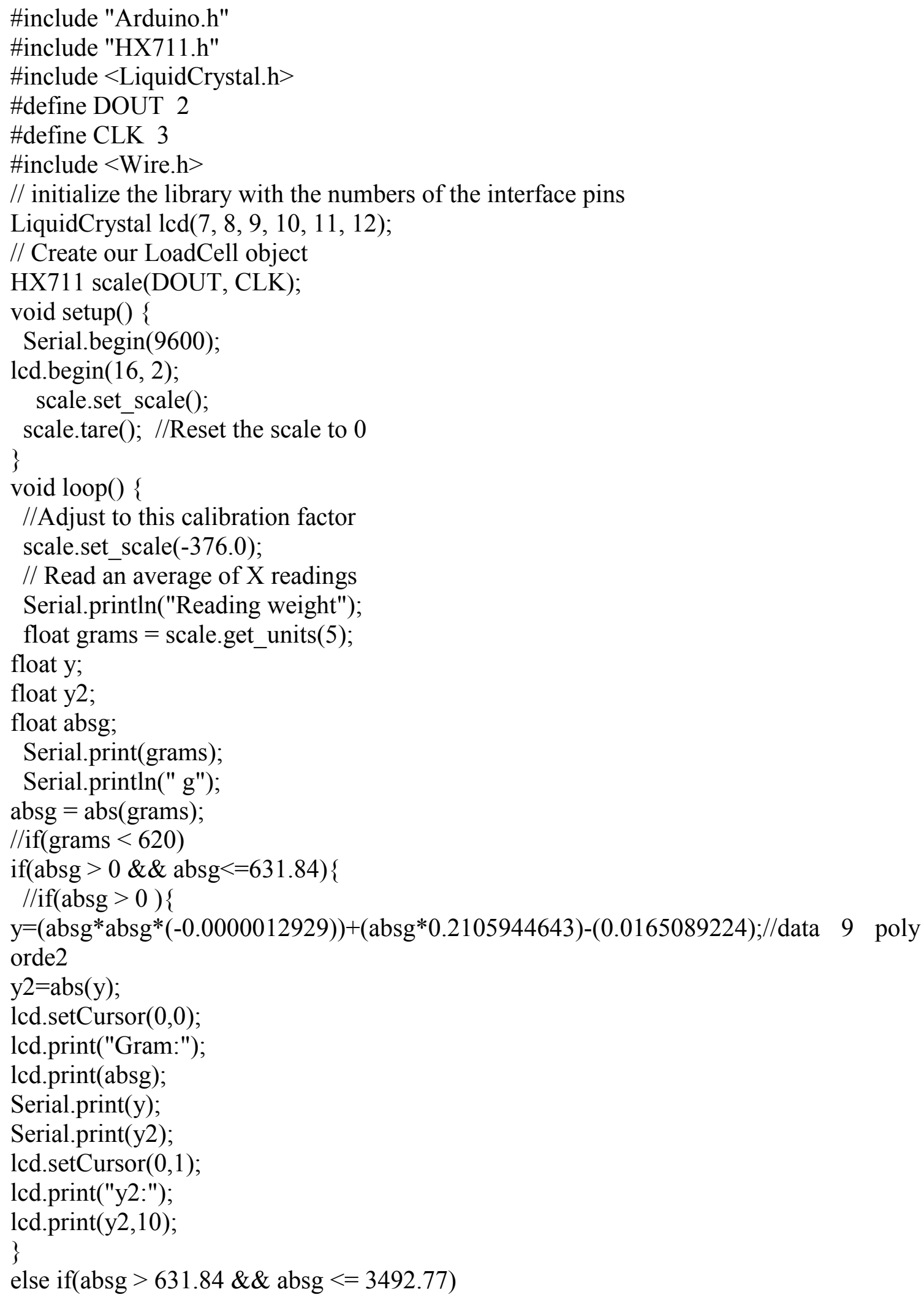




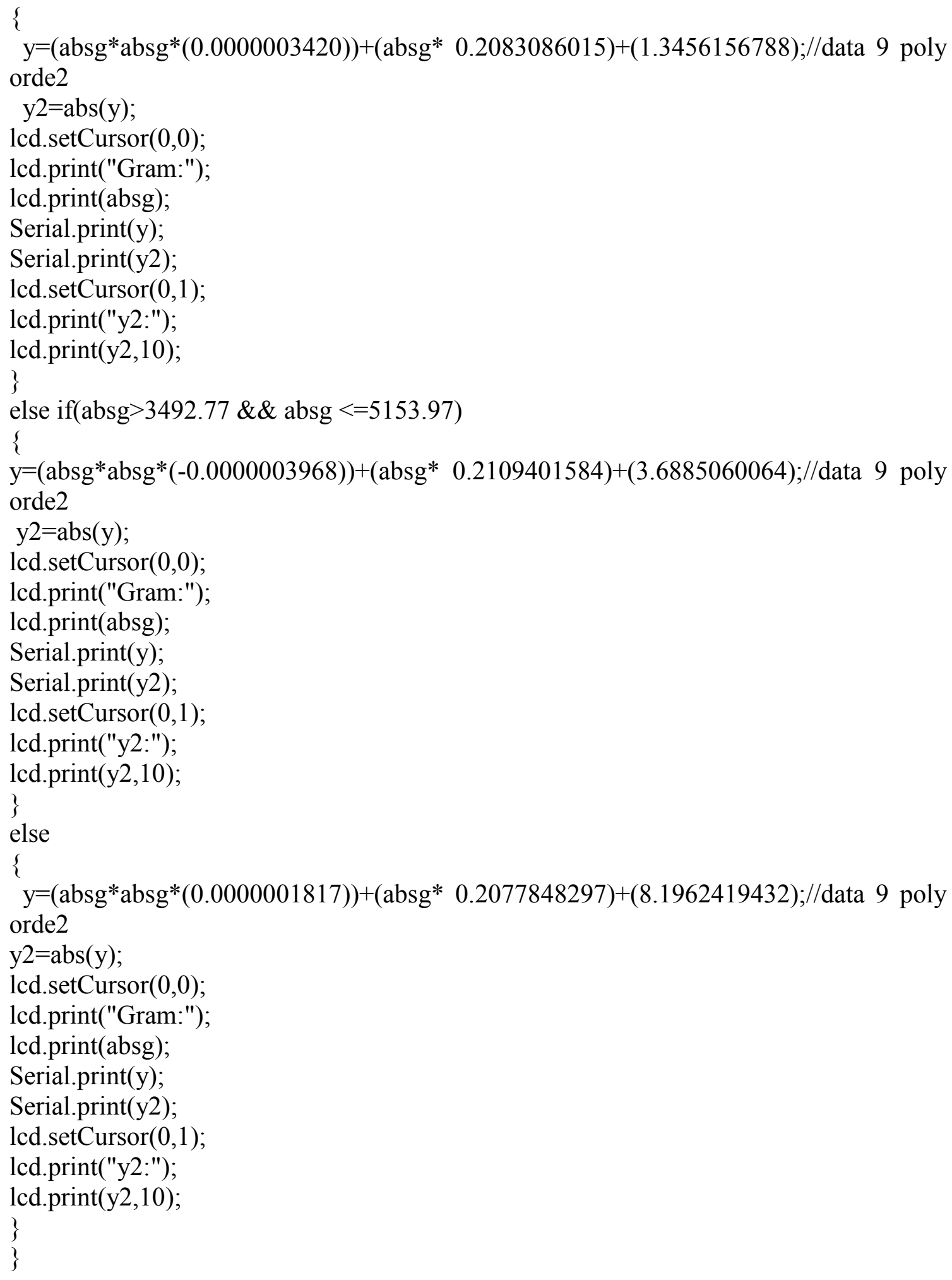

